Teaching \& Learning (2013/2014) 8(1), 1-19

\title{
A Positive Constructivist: An Internal Debate on Opposing Educational Philosophies
}

\author{
DEBORAH WESTON \\ Brock University
}

\begin{abstract}
The purpose of this paper is to reconcile the academic tensions the author experiences between two opposing philosophical epistemologies: positivism and constructivism. The history and epistemological implications of positivism and constructivism are examined. The author debates the use of each philosophy within the context of educational research, linking positivism with quantitative research and constructivism with qualitative research. Teaching practices are examined through the lens of each philosophy. Constructivism is connected to the work of Dewey, Vygotsky, and Piaget, and the use of positivism in educational research is examined in education.
\end{abstract}

\section{Introduction}

A man cannot search either for what he knows or for what he does not know. He cannot search for what he knows - since he knows it, there is no need to search - nor for what he does not know, for he does not know what to look for.

Meno’s dilemma, Plato’s dialogues (Plato, 1997, p. 880)

The purpose of this paper is to reconcile the academic tensions I experience between two opposing epistemologies: positivism and constructivism. ${ }^{1}$ According to Neuman (2000), positivism is associated with a set of epistemological perspectives and philosophies that embrace the scientific method and use numbers to quantify objects of study. He sees constructivism as part of Interpretive Social Science that encompasses epistemological views that knowledge is constructed by researchers and not discovered from the world. The constructivist theory decrees that there is a diversity of methods that are "apprehendable in the form of multiple, intangible

\footnotetext{
${ }^{1}$ For the purpose of this paper, I will use the terms positivism and constructivism to represent these areas of philosophy. I will not explore the many varieties of positivism such as logical empiricism and post-positivism (Neuman, 2000), nor will I examine the variations of constructivism such as hermeneutics and ethnomethodology (Neuman, 2000) within the scope of this paper.
} 
mental constructions, socially and experimentally based, local and specific in nature ... and dependent for their form and content on the individual persons or groups holding the constructions” (Guba \& Lincoln, 1994, pp. 110-111). Constructivist research is primarily qualitative in nature as "qualitative methods come more easily to the human-as-instrument” research methods (Lincoln \& Denzin, 1985, p. 198). In other words, the qualitative constructivist approach captures experiences of people, when people are the subjects being studied.

In my life, I have experienced diversity in work as a geological research assistant, a marketing manager, and now as an educator. This experience has exposed me to both positivists' and constructivists’ epistemologies. My positivistic roots are strong. As a geological research assistant working with microfossils, I used empirical data to seek patterns to develop theories of correlation. As a marketing manager, working in retail, I used marketing research statistics that measured human behaviour, to perform further marketing analysis and guide business decisions.

My experience as an elementary teacher caused an ontological shift in my philosophy and a resulting tension in the way I understood the world. My reality shifted as I went from being a person who made sense of the world through numbers, to a person who saw the world through interconnections and relationships. My educational training and experience guided me towards a constructivist philosophy. The work of Dewey (1859-1952), Vygotsky (1896-1934), and Piaget (1896-1980) formed my educational philosophy, and guided my teaching practice.

The philosophies of positivism and constructivism have opposing ontologies, epistemologies, and research methodologies that cannot be entwined within the same research approach. As an educational researcher, I intend to explore teacher collaboration within teacher learning communities. If I am to use a constructivist philosophical approach to this research, I will focus on qualitative research methods. If I am to use a positivist philosophical approach, I will centre on quantitative research methods. In my research, my epistemological philosophy must match my methodological approach. I must manage the tensions caused by my dilemma and choose only one side of the philosophical divide. In order to conceptualize the theoretical and methodological approaches to my future research, it is important for me to both wrestle with and reconcile, these philosophical ideas. Within this paper, I intend to decide on which side of the philosophical fence I sit, as establishing truths on both sides is incompatible. 


\section{Positivism}

Positivism refers to a philosophy of science which asserts that "objective accounts of the real world can be given” (Denzin \& Lincoln, 2005, p. 27). The nature of the inquiry is anchored in the scientific method of establishing a hypothesis, and testing it against collected data. Positivism adopts a realist ontology, an objectivist epistemology, and an experimental methodology (Guba \& Lincoln, 2005, p. 193). The premise of a realist ontology is that the truth is waiting to be discovered, and that social and physical reality is real (Neuman, 2000). An objective epistemology denotes the philosophy’s framework of seeking rigorous, exact measures, and objective research through the limitation of researcher bias. The positivistic methodology is primarily quantitative in nature and often uses experiments, surveys, and statistics to test hypotheses through empirical analysis (Neuman, 2000).

Positivism is a long standing philosophy that has its roots in the teachings of Plato (427347 B.C.) and Aristotle (384-322 B.C.). Aristotle is credited for developing deductive and inductive reasoning (Robinson \& Groves, 2000). Deductive reasoning is "reasoning that moves from a general statement or principal to a particular point or specific example” (Gutek, 2004, p. 4). Inductive reasoning varies from deductive reasoning, as it "moves from the specific or particular to more general conclusions” (Gutek, 2004 p. 4). Scientific reasoning, also known as the scientific method, was first examined by the inductivist philosopher, Francis Bacon (15611626), who developed the ideas of empirical observation and experimentation (Gorham, 2009).

The use of positivism in social science originates from the work of Auguste Comte (1798-1857), who founded the study of sociology (Neuman, 2000). Comte’s work on positive philosophy presented many positivist principles that are currently used today. John Stuart Mill (1806-1873), another inductivist philosopher, expanded and built upon these principles in his work on logic, by introducing the idea of controlled experiments (Gorham, 2009). Hume (17111776) pointed out errors in inductive reasoning, where "we cannot justifiably derive a universal law or theory from a finite number of empirical observations” (Gorham, 2009, p. 73), meaning that scientific findings based on observations are conjectural and temporary, as they are based on limited, temporal data. Karl Popper (1902-1994), a deductivist, developed the theory of falsification, stating that all theories that are supported by scientific findings are provisional until new contradictory observations are made (Gorham, 2009). He believed that any anomalies in scientific findings would prove that the corresponding theory would also be false. He stated that 
anomalous findings negated the entire theory, and did not consider that there might be some truth in the theory, or as Gorham (2009) puts it, if any part of a theory was proven wrong, then the entire theory would be proven wrong.

For the purpose of this paper, positivism interpreted by social science will be defined as an "organized method for combining deductive logic with precise empirical observations of individual behaviour in order to discover and confirm a set of probabilistic causal laws that can be used to predict general patterns of human activity” (Neuman, 2000, p. 66).

Using an anthropological approach to study how cell biologists examine data in labs, philosopher Latour and sociologist Woolgar, depict "scientific order as a construction of order out of chaos" (1979, p. 33). They contend that science is a "complex network of competition, material exchanges, data massaging, and status-mongering” (Gorham, 2009, p. 121). They state that the scientific method is "widely regarded by outsiders as well organised, logical, and coherent, [but] in fact consists of a disordered array of observations with which scientists struggle to produce order” (Latour \& Woolgar, 1979, p. 36). They pronounce that when scientists are confronted with “a seething mass of alternative interpretations” (Latour \& Woolgar, 1979, p. 36), they impose frameworks that reduce the data that they deem extraneous, and therefore impose their own construction of reality on their field of study.

Gould (1981), a noted palaeontologist, evolutional biologist, and science historian, challenges scientific findings that misuse quantitative data and the scientific method as they are applied to race, intelligence, and human behaviour. He notes that scientists like Morton (1839, 1849) and Blumenbach (1865), used "favourable inconsistencies and shifting criteria ... subjectivity directed toward prior prejudice ... procedural omissions ... [and] miscalculations and convenient omissions” (Gould, 1981, p. 100) to justify claims of inferiority in human race classifications. Gould also critiques the work in establishing human IQ (Intelligence Quotient), stating that IQ is a social construction measuring aptitudes valued by the dominant class (i.e., the people of white European origin). Gould believes that “an uneven IQ distribution would reveal nothing more than social inequity ... and that the debate is itself a clear example of the influence of moral and political values on the direction of science” (cited in Gorham, 2009, p. 140).

Other misrepresentation of quantitative data can be found in contemporary media and scientific literature. A most notable and unconscionable example is the scientific publication of data linking the childhood measles, mumps, and rubella (MMR) vaccine to autism and 
gastrointestinal difficulties in children that was published in the well-respected medical journal, The Lancet (Wakefield et al., 1998). Wakefield and colleagues based their data results on the study of 12 children, which were, in turn, manipulated to discredit the MMR vaccine. This study was later found to be fraudulent, and the paper was retracted by The Lancet (The Editors of the Lancet, 2010). The fallout from the publication of the connection between the MMR vaccine and autism, resulted in a significant reduction of immunization of all vaccines among school-aged children (Smith, Ellenberg, Bell, \& Rubin, 2008), and a resurgence of previously preventable childhood diseases (Dominus, 2011).

Research based on positivism with its quantitative methods and data can be misrepresented and misused, but not all science is purposely distorted. As researchers perceive data through their own perspective, there is always some interpretation by quantitative researchers in the analysis of their data. Quantitative researchers need to be cognizant that their research can never be truly objective, due to researcher bias from imposed frameworks. Gould (1981) states "we have been unable to escape the philosophical tradition that what we can see

and measure in the world is merely the superficial and imperfect representation of an underlying reality” (p. 269).

Positivism is a long developed, yet imperfect philosophy, with its own set of internal controversies. Yet it has endured, and it is still ever present in our society today. As a society, we embrace the positivism philosophy in criminology, marketing research, policy analysis, school administration, program evaluation, and urban planning (Neuman, 2000), to name a few applications. In school environments, positivism is embedded in ministry funding, board decision making, school administration, and student assessment. In addition, with the advent of social networking, our habits and preferences are being harvested into empirical data to be used to target market our consumer consumption (Shirky, 2008). In other words, positivism is pervasive in our society; every time we use and interpret numbers, collected through quantitative methods, we reinforce the significance of positivism in our lives.

\section{Constructivism}

The constructivist epistemology argues that researchers generate knowledge and meaning from an interaction between their experiences and their ideas. Constructivism adopts a relative ontology, a “transactional” epistemology, and a "hermeneutic, dialectical” methodology (Lincoln 
\& Guba, 2000, p 193). A relative ontology uses local and specific constructed and co-constructed realities to explain the existence of being (Guba \& Lincoln, 2005). Transactional epistemology describes the negotiated, subjective nature of knowledge, where knowledge is constructed by researchers. The constructivist methodology is based on a diversity of methods that are interpreted and investigated to construct knowledge. The constructivist methodology is situated in qualitative research, which "consists of a set of interpretive, material practices that make the world visible” (Denzin \& Lincoln, 2005, p. 3). These practices turn the world into a series of representations that transpire as field notes, observations, narratives, interviews, conversations, photographs, recordings, and memos, in which researchers study things in their natural setting, attempting to make sense of, or interpret, phenomena in terms of the meaning people bring to them (Denzin \& Lincoln, 2005). Constructivism contends that there are no essential truths and no objective realities, as they are culturally constructed (Gross \& Levitt, 1994).

As with positivism, constructivism also has its roots in ancient Greek philosophy. Heraclitus (535-475 B.C.) stated that "you cannot step into the same river twice” meaning that “everything flows and nothing stands still” (Guthrie, 1962, p. 488), or in other words, change in the world is absolute. Protagoras, a sophist (490-420 B.C.), is famous for stating that "Man is the measure of all things: of things which are, that they are, and of things which are not, that they are not” (Russell, 1996, p. 83), meaning that all that is real is measured through the context of the human experience. Both philosophers capture the ever changing, subjective nature of human beings, and the cultural landscape in which they live. Kant later developed these emerging ideas, when he suggested that people’s lives inform material realities. Kant argued against Hume, the positivist, that knowledge of the world cannot come from observation alone, but through the lens of human beings’ past experiences (Robinson \& Groves, 2000). Kant believed that our past experiences impact the way we interpret our present experiences. In his work on pure reason, he stated "there exists a knowledge altogether independent of experience, and even of all sensuous impressions" and that "in respect of time ... no knowledge of ours is antecedent to experience, but begins with it” (Kant, 1781, introduction, I.). He believed that this kind of knowledge is in “contradistinction to empirical knowledge” (Kant, 1781, introduction, I.), in which experience follows after knowledge. Kant understood the complementary nature of positivism and constructivism. Georg Wilhelm Friedrich Hegel (1770-1831), developed the dialectic philosophy, where ideas grow and gradually move towards a better grasp of reality or the truth 
(Robinson \& Groves, 2000). Hegel agreed with Kant that human beings' experience of the world involves the mediation or filtering of ideas by our own consciousness, or in other words, truth is conceptually dependent on the way human beings see the world. Hegel believed that human consciousness is not fixed, but is continually changing (like Heraclitus's river), and that it develops new categories and concepts that determine how human beings see the world (Robinson \& Groves, 2000).

Social science, related to constructivism, can be traced back to Wilhem Dilthey (18331911), and Max Weber (1864-1920). Weber embraced Dilthey’s idea of empathetic understanding (i.e., Verstehen). He argued that in order to understand how human beings shape their behaviour and make decisions, we need to study meaningful social action (Neuman, 2000). He wrote that sociology is:

the science whose object is to interpret the meaning of social action and thereby give a causal explanation of the way in which the action proceeds and the effects which it produces. By 'action' in this definition is meant the human behavior when and to the extent that the agent or agents see it as subjectively meaningful ... [where] ... 'meaning' [is] to be thought of as somehow objectively 'correct' or 'true' by some metaphysical criterion. (quotes as noted, Weber, 1922, p. 7)

Interpretive social science is related to hermeneutics, a theory of meaning that emphasises the detailed reading or examination of text to discover the embedded meaning within the text (Neuman, 2000). Upon adopting this theory, researchers bring their subjective experience into reading and finding meaning in the text. In interpretive social science "true meaning is rarely simple or obvious on the surface; one reaches it only through a detailed study of the text, contemplating its many messages and seeking the connections among its parts” (Neuman, 2000, p. 71).

Constructivism, as a subset of interpretive social science, was developed further by Jacque Derrida (1930-2004), and Michael Foucault (1926-1984), who were both concerned with the use of language, which they understood was always influenced by social context (Matthews, 2003). They believed that socially constructed reality is constituted through language and organized through narrative (Matthews, 2003). 
In the $20^{\text {th }}$ century, constructivism was applied to education as part of the progressive education movement. Significant contributions to this change in educational philosophy have been through the works of John Dewey, Lev Vygotsky, and Jean Piaget. Prior to the $19^{\text {th }}$ century, children were thought to be blank slates (a term coined by John Locke, 1632-1704), to which knowledge was downloaded into their minds, and play and experience were considered aimless and of little importance. Piaget challenged this thought by stating that play is an essential part of children's cognitive and social development, and that education should be child-directed, not teacher-directed (Matthews, 2003). According to Piaget (1973), children are operational thinkers who progress through three stages of thinking: (a) preoperational (magical thinking, ages 1 to 7), (b) concrete (concrete thinking, ages 7 to 11), and (c) formal operational (abstract thinking, ages 11 to 16). Piaget believed that teachers should adapt their teaching practice to the students' stages of cognitive development. He viewed the role of the teacher as a facilitator of learning to help students construct knowledge:

It is obvious that the teacher as organizer remains indispensable in order to create the situations and construct the initial devices which present useful problems to the child. Secondly, he [the teacher] is needed to provide counter-examples that compel reflection and reconsideration of over-hasty solutions. What is desired is that the teacher cease being a lecturer, satisfied with transmitting ready-made solutions; his [the teacher's] role should rather be that of a mentor stimulating initiative and research. (Piaget, 1973, p. 16)

Vygotsky (1978) coined the term Zone of Proximal Development, as the "distance between the actual developmental level as determined by independent problem solving and the level of potential development, as determined through problem solving under adult guidance, or in collaboration with more capable peers” (p. 86). The idea of scaffolding or instructional scaffolding is credited to be developed by Jerome Bruner (Wood, Bruner, \& Ross, 1976). Due to the interactional supportive learning process within the Zone of Proximal Development, the term scaffolding is often referred to in Vygotsky’s work (Cazden, 1983). Scaffolding represents the supportive interactions between teacher and student that enable the student to do something beyond his or her autonomous efforts. 
John Dewey (1859-1952) believed in a continuum in learning, in which learning and growth extend beyond an initial experience, and he argued that "the principal of continuity of experience means that every experience both takes up something from those which have gone before and modifies in some way the quality of those who come after" (1938a, p. 35). He understood that the process of maturing as a human being was not only physical, but intellectual and moral, and was an "exemplification of the continuity” of growth (Dewey, 1938a, p. 36). Dewey (1897) thought that the purpose of education should not revolve around the acquisition of a pre-determined set of skills, but was "to prepare him [the student] for the future life means to give him [the student] command of himself; it means so to train him [the student] that he will have the full and ready use of all his capacities” (p. 77). Dewey (1897) proposed that preparing children for the uncertain future allowed future citizens to have the capacity and skills to be able to react to changes in society. He stated that the "very idea of education as a freeing of individual capacity in a progressive growth directed to social aims. Otherwise a democratic criterion of education can only be inconsistently applied” (Dewey, 1916, p. 64). In other words, a well prepared society of individuals allows for the consistent application of the democratic process.

Dewey did not see students as blank slates (as Locke did) to be filled with knowledge. He believed that learning should be experiential:

in determining the place of thinking in experience we first noted that experience involves a connection of doing or trying with something which is undergone in consequence ... thinking is the accurate and deliberate instituting of connections between what is done and its consequences. It notes not only that they are connected, but the details of the connection. (Dewey, 1916, p. 123)

Dewey's experiential, student-centred philosophy of education clearly falls within the parameters of constructivism, where students generate knowledge and meaning from an interaction between their experiences and their ideas.

In Dewey’s (1938b) work Logic: The theory of inquiry, he discusses the structure of inquiry and the scientific method as related to his thoughts on the experiential continuum and the continuity of inquiry, stating that the "principal of the 'long-run' phase of knowledge [is] connected with the self-developing and self-correcting nature of scientific inquiry” (p. 489), thus 
advocating for the use of scientific inquiry. Dewey was a great enthusiast "for the successes of science and its methods of inquiry” (Robinson \& Groves, 2000, p. 111), and believed in maintaining a scientific approach to human problems. He encouraged children attending his laboratory school to invent hypotheses and test them, as well as participate in problem based learning (Robinson \& Groves, 2000). Given that the scientific inquiry and its methodology are both positivistic in nature, I wonder, given the choice, which epistemology, constructivist versus positivist, Dewey would philosophically endorse?

\section{The Debate}

In this section of the paper, I will analyze which philosophy, positivism or constructivism, best fits my outlook of how I define truth. Looking through a positivist epistemological lens, I view knowledge as something that can be discovered, predicted, and verified. From my ontological perspective, I believe that truth has a physical and social reality. Through the structure of the scientific method, I establish truth by setting hypotheses, collecting data, and making judgements in my inquiry. With this positivistic approach, I acknowledge the role of bias in information, and try to limit the influence of my own bias and the bias of others. My positivistic methodology is quantitative in nature, as I often rely on numerical data, using a positivist axiology or principals of establishing worth, to help with making decisions.

As an elementary teacher, I regularly use a positivistic approach to evaluate my students. I measure my students' learning through student assessment results. Assessment information:

is used by the teacher to summarize learning at a given point in time. This summary is used to make judgements about the quality of student learning on the basis of established criteria, to assign a value to represent that quality, and to support the communication of information about achievement to students themselves, parents, teachers, and others. (Ontario Ministry of Education, 2010, p. 31)

This assessment of learning is summative and evaluative in nature. It is the "assessment that becomes public and results in statements or symbols about how well students are learning” (Western and Northern Canadian Protocol, p. 55, cited in Ontario Ministry of Education, 2010, p. 31). These are the data shown on student report cards in the form of letter or number grades. The 
public expects the data to be valid and reliable. In Ontario, assessment and evaluation has moved from norm-referenced to criterion-referenced:

This means that teachers assess and evaluate student work with reference to established criteria for four levels of achievement that are standard across the province, rather than by comparison with work done by other students, or through the ranking of student performance, or with reference to performance standards developed by individual teachers for their own classrooms ... criterion-referenced assessment and evaluation ensure that the assessment and evaluation of student learning in schools across the province are based on the application of the same set of well-defined performance standards. The goal of using a criterion-based approach is to make the assessment and evaluation of student achievement as fair, reliable, and transparent as possible. (Ontario Ministry of Education, 2010, p. 31)

Even with these guidelines, absolute objectivity of the data is not always present, as teachers use their “professional judgement and interpretation of evidence and should reflect the student's most consistent level of achievement, with special consideration given to more recent evidence” (Ontario Ministry of Education, 2010, p. 39) to establish the report card grades.

It is worth noting, right from the start, that assessment is a human process, conducted by and with human beings, and subject inevitably to the frailties of human judgement. However crisp and objective we might try to make it, and however neatly quantifiable may be our "results", assessment is closer to an art than a science. It is, after all, an exercise in human communication. (Sutton, p. 2, cited in Ontario Ministry of Education, 2010, p. 29)

As an elementary teacher, I use the guidelines set out in the Ontario Ministry of Education's assessment document, Growing success: Assessment, evaluation, and reporting in Ontario schools (2010), to evaluate my students' achievements. As a teacher, I am expected to be accountable for my students' learning, and the grades that evaluate their performance based on specific measures (Valli \& Buese, 2007). Regardless of my philosophical orientation and 
pedagogical approach in my teaching practice, it is the students' performance evaluations on the report card that the majority of parents deem most important.

My academic and work experience in science and business is also rooted in positivism and quantitative inquiry. As a research assistant, I used statistical correlation analyses to determine associations between microfossils. My work in market research required me to use feedback in the form of customer comment card data, to determine the effectiveness of various locations in a well known restaurant chain. For a well known retail store, I used household data, broken down by postal code from Statistics Canada, to determine which households would be more likely to be interested in the retailer's products. From there, I determined what percentage of advertising flyers would be sent to households in each postal code. We used marketing data to predict sales and establish advertising budgets. In my business experience, the use of numerical data using quantitative methods, was a key tactic in making predictions and decisions.

Upon entering my training in education, my philosophical viewpoint shifted from a positivistic philosophy to a constructivist philosophy. I was introduced to the works of Dewey, Vygotsky, and Piaget. Through teaching, my ontological assumptions were embedded in a childcentred approach to teaching and learning. Piaget’s work (1973) facilitated my understanding of the transition that occurs in students between the stages of concrete and abstract thinking. I responded to this knowledge by developing lessons that were hands-on and experiential in nature, to help my students bridge the gap between their concrete learning and the abstract ideas. Vygotsky’s work (1978) made me appreciate the interplay that occurs between teacher and student in the role of learning, and the importance of instructional scaffolding. His work reinforced my belief in the importance of being a mentor and facilitator in my role as a teacher.

Dewey’s work $(1916,1938 a)$ had the greatest impact on me. As someone who constructs my own learning through experience, I understand his concept of continuity of experience where humans adapt their knowledge, by incorporating previous learning and modifying it with new learning. Dewey’s idea of continuity includes a sense of a continuum as part of human development, where growth includes previous experiences that have affected human existence (Fott, 1998). Dewey's continuity implies that children are not blank slates, and come to school with a past full of experiences that will impact their learning. As Dewey connects informed citizens with democracy, I too put great value in his idea of education's importance in developing students as future citizens. Dewey’s (1916, 1938a) work reinforced my appreciation 
for the idea of education for all students, and the role democracy plays in developing students into engaged citizens. This work provided me with the inspiration to advocate for education for all students, regardless of ability. Dewey (1916) stated:

Since growth is the characteristic of life, education is all one with growing; it has no end beyond itself. The criterion of the value of school education is the extent in which it creates a desire for continued growth and supplies mean for making the desire effective in fact. (p. 62)

Dewey (1916, 1938a) also believed that education was a function of a naturally occurring developmental process unique to a child, and that the child's educational development had to emerge, rather than be forced by an external agent such as a teacher (Stone, 1996). Given this belief, any intervention with this process, such as teacher-directed instruction, would impact a student's developmental process, or even do harm (Matthews, 2003). Constructivist teachers tend to be learner-centred or discovery-centred, using strategies such as authentic learning, hands on learning, and context-based learning (Matthews, 2003).

I embraced the philosophy of the constructivist teacher and the resulting classroom teaching practices. But when I examined the constructivist approach further, I came across research that questioned the impact of constructivist teaching practices. Based on Piaget's work, constructivist teachers believe they need to adapt their teaching style, approach, and content to the specific developmental stage of the child. Matthews (2003), however, points out that "there is no empirical evidence supporting the notion that matching teaching and learning styles has any effect on educational outcome” (p. 58). The constructivist teacher believes that social interaction is important, and that context is necessary for learning to occur, yet Matthews argues that contextualized learning rejects the importance of decontextualized learning, where large tasks are broken down into smaller ones. The constructivist teacher relies on student-oriented intrinsic motivation, as constructivists believe that the use of drill, corrective feedback, and external incentives are inhibitory to the natural learning process (Deci \& Ryan, 1985). Critics of constructivist teaching methods such as Mayer (2000), and Kirschner, Sweller, and Clark (2006), state that the empirical evidence does not support the constructivist teaching technique of pure 
discovery. Instead, Mayer (2004) recommends using guided discovery, which is a combination of direct instruction and hands-on activity. Mayer (2004) states:

Pure discovery - even when it involves lots of hands-on activity and large amounts of group discussion - may fail to promote the first cognitive process, namely, selecting relevant incoming information. In short, when students have too much freedom, they may fail to come into contact with the to-be-learned material. There is nothing magical to insure that simply working on a problem or simply discussing a problem will lead to discovering its solution. If the learner fails to come into contact with the to-be-learned material, no amount of activity or discussion will be able to help the learner make sense of it. (p. 17)

Mayer (2004) summarizes by saying that "in many ways, guided discovery appears to offer the best method for promoting constructivist learning. The challenge of teaching by guided discovery is to know how much and what kind of guidance to provide and to know how to specify the desired outcome of learning” (p. 17). Given Mayer's stance on guided discovery, I wonder where the line is drawn between constructivist's highly scaffolded teaching instruction, and positivist's teacher-directed teaching instruction.

Upon analyzing and reflecting on my teaching practice, I realize that I employ both student-centred and teacher-directed instruction. Depending on the activity and the background knowledge of the students, some lessons are very teacher-directed. I often have to break down tasks for students, taking their learning out of the context of the lesson. Teaching spelling and grammar is a good example of decontextualized learning, as the material is removed from the context of the students' writing.

The observable reality is that I use a number of strategies in my teaching practice, some of which do not fall within the constructivist framework. My instruction is differentiated for each student as some students need more teacher support than others. I may embrace the idea of the constructivist teacher, but the reality is my practice is an amalgam of a number of different approaches to teaching, learning, and assessment.

As a teacher, I am expected to produce results in student achievement measured through grades, but I measure the effectiveness of my practice through student observations, student 
conversations, and anecdotal notes. I instead use my professional judgement to evaluate my own performance as a teacher. Teachers are asked to implement various initiatives in the form of the latest instructional strategy. The effectiveness of these initiatives is rarely measured; administrators and teachers are left to evaluate these initiatives with unproven beliefs, anecdotal experiences, and the current social/political value of the latest initiative (Matthews, 2003). Quantitative methods are not regularly used to assess the effectiveness of teaching practices. There is no test of validity and reliability of teaching practices overall. "Schools of education, with some exceptions, have failed to train teachers in the application of the scientific method to the field of education, while continuing to espouse empirically unsupported constructivist teaching practices” (Matthews, 2003, p. 62). In the end, I am left to evaluate my own teaching practices through the qualitative, constructivist methods of anecdotal notes, observations, and conversations, in an educational landscape that expects me to work in a quantifiable, positivistic framework of assessment and evaluation.

Through the writing of this paper, I realize that although I believe in the idea of constructivism, in fact I am a positivistic pragmatist. I believe that human behaviour and learning can be identified and quantified, and that human behaviour can be predicted given specific circumstances. Furthermore, in seeing research through a positivist lens, I can make sense of some of the complexities of human interactions; I can use this approach in my research to possibly identify key points that may either enhance or restrict teacher collaboration within learning communities. I understand that with the introduction of new information, my reality can change and that there is always a probability that some data may not be reliable and valid. In other words, I can only assess reliability and validity given the present knowledge I possess. With the introduction of new information, my point of reference in determining reliability and validity could change.

When I first came to this conclusion, I was not comfortable. My academic introduction to positivism, through an educational philosophy lens, made me see it as outdated and not fitting into the postmodern world. The idea of constructivism in education is more desirable, because its student-centred approach nurtures learners’ intrinsic motivation to learn. Constructivism sees the world through the human perspective, and provides a flexible framework to interpret and adapt to the changing educational landscape (as referenced to Heraclitus’s ever changing river). Constructivism also supports the idea of promoting learning skills and work habits, as embodied 
in the most recent change to Ontario’s public school report cards (Ontario Ministry of Education, 2010).

I believe my initial negative reaction to positivism is due to the tensions I experienced between my knowledge of an ever-changing world, and the idea that quantitative data must be the absolute truth. After exploring the history of positivism, I realized that there is space in positivism and its quantitative methodology for a level of uncertainty, as this data is a “superficial and imperfect representation of an underlying reality” (Gould, 1981, p. 269). The misuse and misrepresentation of quantitative data in many aspects of society, science, business, and the media, also caused me frustration, and made me view positivism in a negative light. The best way to counter this misuse is to represent research data in a principled, transparent manner, stating what can be measured in the data, and what the limitations are in using quantitative methods.

\section{Conclusion}

My academic tensions have been reconciled, and I sit firmly on the positivistic side of the philosophical fence. I was surprised to discover that I am philosophically a positivist. I knew I favoured quantitative data, but I did not realize that my truths were reflected in the use of this data. If I had not closely examined my actual practices and beliefs, I would still have a philosophical crush on constructivism. Upon entering the education field, my ontological shift from positivism to constructivism was a shift in concept, but not in reality. My philosophical view of the world did not match the observable reality of my teaching practice, or how I negotiate my path through life.

Modern science has given human beings access to a mysterious and unfamiliar world. Our view of the world is ever changing, as innovative technology offers fresh perspectives of how we see ourselves and the spaces in which we live (Gorham, 2009). Due to the complexity of the world, we must construct a framework in which to interpret our environment. As the well known American intellectual, writer, reporter, and political commentator, Lippmann (1922) puts it:

For the real environment is altogether too big, too complex, and too fleeting for direct acquaintance. We are not equipped to deal with so much subtlety, so much variety, so 
many permutations and combinations. And we have to reconstruct it on a simpler model before we can manage with it. (p. 20)

Lippmann's words especially hold true with the vast amount of information that is available through the Internet, and therefore we each construct a simpler model (or framework), so we can comprehend this data. In order to see through a positive perspective, some construction of reality is needed to make sense of our world. The construction of our framework will ultimately be influenced by our bias. Being aware of how our bias impacts our reality, is essential to avoid misinterpreting what we see and how we comprehend it, and thus imposing our own reality on the data.

I leave this paper with a deeper knowledge of philosophical epistemologies. In addition, I have a clearer understanding of my epistemological and ontological roots, and my preferred methodology research approach, as it relates to educational contexts. To avoid the misuse of data, in my future research, I intend to ensure I acknowledge my researcher bias, so I will be as transparent as possible. As Weinberger (2009) puts it, “Transparency is the new objectivity. Transparency gives the reader information by which she can undo some of the unintended effects of the ever-present biases. Transparency brings us to reliability the way objectivity used to" (n.p.).

In conclusion of this paper, I walk away with my positivistic feet firmly placed on real ground.

- How do these ideas inform others based on your tensions with these as an educator?

- Is future research needed on this? If so, what might it look like?

- How does this work inform what you say you are going to do on p. 2 (“explore teacher collaboration within teacher leaning communities”...)?

- Where does this leave you methodologically?

Deborah P. A. Weston, B.Sc., B.Com., B.Ed., M.Ed. is a full-time middle school teacher at the Peel District School Board, and a part-time Ph.D. Candidate at Brock University. Her research interests include integrated curriculum, multiple literacies, teacher collaboration, learning communities, and quantitative research. She regularly uses research to test new ideas in her classroom and to promote the reflection of her classroom practice, in order to narrow the gap between her practice and her vision. 


\section{References}

Blumenbach, J. F. (1865). Anthropological treaties. London, UK: Longman, Green, Longman, Roberts, and Green.

Cazden, C. B. (1983). Adult assistance to language development: Scaffolds, models, and direct instruction. In R. P. Parker \& F. A. Davis (Eds.), Developing literacy: Young children's use of language (pp. 3-17). Newark, DE: International Reading Association.

Deci, E. L., \& Ryan, R. M. (1985). Intrinsic motivation and self-determination in human behavior. New York, NY: Plenum.

Denzin, N. K., \& Lincoln, Y. S. (2005). The Sage handbook of qualitative research (3rd ed.). Thousand Oaks, CA: Sage.

Dewey, J. (1897). My pedagogic creed. School Journal, 5, 77-80.

Dewey, J. (1916). Democracy and education. Whitefish, MT: Kessinger Publications.

Dewey, J. (1938a). Experience and education. New York, NY: Simon \& Schuster.

Dewey, J. (1938b). Logic: The theory of inquiry. New York, NY: Holt.

Dominus, S. (2011, April 20). The crash and burn of an autism guru. New York Times Magazine.

The Editors of The Lancet. (2010, February). Retraction--Ileal-lymphoid-nodular hyperplasia, non-specific colitis, and pervasive developmental disorder in children. The Lancet, 375(9713), 445.

Fott, D. (1998). John Dewey: America's philosopher of democracy. Cumnor Hill, Oxford, UK: Rowman and Littlefield Publishers.

Gorham, G. (2009). Philosophy of science. Oxford, UK: Oneworld Publications.

Gould, S. J. (1981). The mismeasurement of man. New York, NY: W. W. Norton \& Co.

Gross, P. R., \& Levitt, N. (1994). Higher superstitions: The academic left and its quarrels with science. Baltimore, MD: Johns Hopkins University Press.

Guba, E. G., \& Lincoln, Y. S. (1994). Competing paradigms in qualitative research. In N. K. Denzin \& Y. S. Lincoln (Eds.), Handbook of qualitative research (pp. 105-117). Thousand Oaks, CA: Sage.

Guba, E. G., \& Lincoln, Y. S. (2005). Paradigmatic controversies, contradictions, and emerging influences. In N. K. Denzin \& Y. S. Lincoln (Eds.), The Sage handbook of qualitative research (3rd ed.), (pp. 191-215). Thousand Oaks, CA: Sage.

Gutek, G. L. (2004). Philosophical and ideological voices in education. Toronto, ON: Pearson.

Guthrie, W. K. C. (1962). A history of Greek philosophy: The earlier presocratics and the Pythagoreans. New York, NY: Cambridge University Press.

Kant, I. (1781). Critique of pure reason. (J. M. D. Meiklejohn, Trans.). London, UK: Henry G. Bohn.

Kirschner, P. A., Sweller, J., \& Clark, R. E. (2006). Why minimal guidance during instruction does not work: An analysis of the failure of constructivist, discovery, problem-based, experiential, and inquiry-based teaching. Educational Psychologist, 41(2), 75-86.

Latour, B., \& Woolgar, S. (1979). Laboratory life: The social construction of scientific facts. Princeton, NJ: Sage.

Lincoln, Y. S., \& Denzin, N. K. (1985). Naturalistic inquiry. Beverly Hills, CA: Sage.

Lincoln, Y. S., \& Guba, E. G. (2000). Paradigmatic controversies, contradictions, and emerging Influences. In N. K. Denzin \& Y. S. Lincoln (Eds.), The Sage handbook of qualitative research (2nd ed.), (pp. 163-188). Thousand Oaks, CA: Sage.

Lippmann, W. (1922). Public opinion: An important work of the theory of public opinion in 
relation to traditional democratic theory. New York, NY: Harcourt, Brace and Company.

Matthews, W. J. (2003). Constructivism in the classroom: Epistemology, history, and empirical evidence. Teacher Education Quarterly, 30(3), 51- 64.

Mayer, R. E. (2000). What is the place of science in educational research? Educational Researcher, 29(6), 38-39.

Mayer, R. E. (2004). Should there be a three-strikes rule against pure discovery learning? The case for guided methods of instruction. American Psychologist, 59(1), 14-19.

Morton, S. G. (1839). Crania Americana or a comparative view of the skulls of various aboriginal nations of North and South America. Philadelphia, PA: John Pennington.

Morton, S. G. (1849). Observations on the size of the brain in various races and families of man. Proceedings of the Academy of Natural Sciences Philadelphia, 4, 221-224.

Neuman, W. L. (2000). Social research methods (4 ${ }^{\text {th }}$ ed.). Boston, MA: Allyn \& Bacon.

Ontario Ministry of Education. (2010). Growing success: Assessment, evaluation, and reporting in Ontario schools (1st ed.). Toronto, ON: Ontario Ministry of Education.

Piaget, J. (1973). To understand is to invent: The future of education. New York, NY: Grossman.

Plato. (1997). Plato's Complete Works. J. M. Cooper (Ed.). Indianapolis, IN: Hackett Publishing Company.

Robinson, D., \& Groves, J. (2000). Introducing philosophy. Duxford, Cambridge, UK: Icon Books.

Russell, B. (1996). History of western philosophy. London, UK: Routledge.

Shirky, C. (2008). Here comes everybody. New York, NY: Penguin Press.

Smith, M. J., Ellenberg, S. S., Bell, L. M., \& Rubin, D. M. (2008). Media coverage of the measles-mumps-rubella vaccine and autism controversy and its relationship to MMR immunization rates in the United States. Pediatrics, 121(4), 836-43.

Stone, J. E. (1996). Developmentalism: An obscure but pervasive restriction on educational improvement. Educational Policy Analysis Archives, 4(8), 1-73.

Sutton, R. (1991). Assessment: A framework for teachers. London, UK: Routledge.

Valli, L., \& Buese, D. (2007). The changing roles of teachers in an era of high-stakes accountability. American Educational Research Journal, 44(3), 519-558.

Vygotsky, L. S. (1978). Mind in society: Development of higher psychological processes, Cambridge, MA: Harvard College.

Wakefield, A. J., Murch, S. H., Anthony, A., Linnell, J., Casson, D. M., Malik, M., ... WalkerSmith, J. A. (1998). Ileal-lymphoid-nodular hyperplasia, non-specific colitis, and pervasive developmental disorder in children. The Lancet, 351(9103), 637-41.

Weber, M. (1922/1991). The nature of social action. In W. G. Runciman (Ed.), Weber: Selections in translation. (E. Matthews, Trans.). New York, NY: Cambridge University Press.

Weinberger, D. (2009, September). Transparency: The new objectivity. Trend-Setting Products 2009, 18(8).

Western and Northern Canadian Protocol for Collaboration in Education. (2006). Rethinking classroom assessment with purpose in mind. Winnipeg, MB: Manitoba Education, Citizenship and Youth.

Wood, D., Bruner, J., \& Ross, G. (1976). The role of tutoring in problem solving. Journal of Child Psychology and Psychiatry, 17, 89-100. 